\title{
Sociolinguistic-cum-pedagogic Implications of Anglicisation: Evidence from Igbo Toponyms
}

\author{
OBITUBE, Kelvin Francis \\ Department of Linguistics, Igbo and Other Nigerian Languages, University of Nigeria, Nsukka, Nigeria \\ OKEKE, Chukwuma Onyebuchi \\ Department of Linguistics, Igbo and Other Nigerian Languages, University of Nigeria, Nsukka, Nigeria
}

\begin{abstract}
Naturally, a group's urge to protect all aspects of its language against negative sociolinguistic influences is a task carried out with all dedication because a group's language identifies them, tells their story and showcases their cultural heritage. Presently, Igbo toponyms are seriously threatened by anglicisation. The paper's main objectives are to highlight the various forms of anglicisation observed in Igbo toponyms, their negative influences on the Igbo language, and how to overcome this negative sociolinguistic phenomenon. The paper adopts a qualitative analysis approach; and observes that Igbo toponyms are actually anglicised, following the trend left by the British by adding ' $r$ ', ' $h$ ', 'aw', etc., with negative effects such as wrong spelling and meanings of Igbo toponyms, loss of history and cultural heritage of the Igbo etc. If this negative sociolinguistic phenomenon is left unchecked, potential loss of some letters of the Igbo alphabet and the Igbo language endangerment, are imminent.
\end{abstract}

Index Terms - toponym, anglicisation, Igbo letters, cultural heritage, foreign encroachment, Igbo language endangerment

\section{INTRODUCTION}

Apart from the widely acknowledged fact about language as a medium of expression, another key role that language plays in the lives of a people is giving every ethnically or culturally differentiated group of people a unique identity. Language as an identity marker manifests as people are recognised by the language they speak, or are differentiated from another or some other group(s) of people who speak another or some other variety/varieties of language with. The fact that the language of a people is an important part of their cultural make-up supports the fact that their identity manifests in both the spoken and written forms of their language. Speaking and writing of the Igbo language is synonymous with the cultural values and traditions of the Igbo, and on a broader level, showcases the identity of the Igbo. The Igbo language possesses its own features which are different from the features of the English language, which is the language of the former colonial masters of the Igbo nation.

Over the years, the influence of the British has resulted in the nglicisation of the spellings of place names and other terms in the Igbo language. By nglicisation we mean the adoption of the spelling convention of the English language in the spelling of Igbo words. The nglicisation of Igbo words is observed to be continually on the rise, especially with regard to names of places. The most obvious cases are found in the names of places within the Igbo geographical region. This study, therefore, makes an inquiry into the nature of nglicisation of Igbo place names in order to account for the manifestations of this sociolinguistic phenomenon and highlight its effects on the Igbo language. Specifically, this study has the following objectives:

i. to point out the alterations in Igbo place names as a result of anglicisation and

ii. to highlight the effects of anglicisation of Igbo place names on the Igbo language and culture.

The paper is made up of five sections. Section one introduces and presents the background to the study. In section two, the authors provide the theoretical background of the study in order to properly situate the present research work and fill the needed academic vacuum. Sections three, four and five, deal with the research methodology, data presentation and analysis respectively, while sections six and seven summarises and concludes the paper respectively.

\section{CONCEPTUAL FRAMEWORK}

This section of the paper provides the operational definitions of some key concepts in this study. In doing this, the concept of place name comes to mind. Shamhrain (1999) defines place name as that name which indicates features of landscape, from the peaks and valleys, rivers and marshes of a given locality, to wide mountain ranges or entire natural region. According to him, place names also describe human habitations and land units of varying scope and function, from transient occupation sites to settled communities, from individual holdings to extensive administrative division.

In tandem with the study of place names, the concept of toponym also comes to mind. Hutabarat and Pratama (2016) define toponym as the place name or geographical name, while the study of toponyms, their origins, meanings, use, and typology is called toponymy. In the words of DeLozier (2016, p. 32), "Toponyms are named geographic entities. The 
entities they denote exist at a variety of geographic scales, from the largest-earth, down to much smaller entities, bus stops, intersections, and buildings." In other words, toponym is equally regarded as the general name for any place or geographical entity.

For a concise view representing the idea of the concept adopted and put forward in this paper, the definition of toponym and toponymy provided by Domingues and Eshkol-Taravella (2015), which they derived from the postulations of the French National Mapping Agency, IGN, is adopted. They define toponym as the one or several word name(s) of a place referring closely to a geographically located detail and to a group of people who use it. Furthermore, they state that toponym distinguishes between inhabited and uninhabited places, places with relief, rivers, lanes and microtoponyms such as building names. Therefore, this paper adopts Domingues and Eshkol-Taravella's (2015) definition of toponymy that sees the term as the study of place names as an integral part of man's relationship with his environment, culture and his entire world. Also, this study sees place name and toponym as synonyms.

With respect to place names/toponyms, the effect of anglicisation in so many places and regions of the world has become a notable and contentious issue and enunciating this concept becomes imperative because of its negative effects on languages, especially the Igbo language. Mukerjee (1958) and Price (2007) share similar view that in terms of language, anglicisation is a policy on the use of the English language. Price (2007) particularly sees anglicisation as the process of adapting a name to make it look more like an Anglo-Saxon name so that it is easier for English speakers to use. World heritage encyclopaedia (2016) has it that Calvin Veltman, following the methods of analysis developed in Quebec, Canada for establishing language shift, used the term to refer to the practice of individuals in minority language groups who cease using their mother tongue as their preferred language and adopt English instead. Over time, the term usually refers to the process of altering the pronunciation or spelling of a foreign word when it is borrowed into English. The encyclopaedia continues that personal names may also be anglicised, and this was common for names of antiquity or of foreign heads of state, and it has also been common among immigrants to English-speaking countries.

Scholars such as Coupland and Thomas (1990), as well as Bridge and Fedorowich (2003) see anglicisation, which is equally referred to as Englishing, as the process of converting something to more "English" norms, thus, abandoning the original norms of the word in question, respelling of foreign words, often to a more drastic degree than Romanisation (which is adapting a name to make it look like a Roman name following the Roman phonotactic rules and spelling pattern). Anglicisation within a language is adapting oral or written elements of any other language into a form that is more comprehensible to a speaker of English; or in general, of altering something so that it becomes English in form or character (Sura's supreme English-English-Tamil dictionary: Revised, enlarged and updated, 2005). These various definitions represent similar and diverse views of anglicisation. However, for the purpose of this paper, anglicisation is seen as an act and process of adopting the English language convention in the representation of non-English names; especially, non-English toponyms.

\section{TheORETICAL BACKGROUND OF THE STUDY}

This study adopts the framework of causal theory of reference proposed by Kripke (1980) to account for how names acquire explicit referents based on evidence. The causal theory is a reaction to the descriptive theory of name by Russell (1905) and Frege (1952), which holds that to successfully use a name to refer to an object, one has to be acquainted with peculiar identifying description of the object. The idea of causal theory is that a place name refers to a particular location because there exists a special sort of causal relationship between the use of the name and the referent, that is, the place to which the name refers. According to Kripke (1980), what makes it possible for one to use a name to successfully refer to a place is not being acquainted with a set of descriptions associated with it but the use of the name is only caused by an appropriate naming of the location based on the topography of the place, experiences of the inhabitants, events that took place there etc. The causal theory uses histories and physical causes to explain language use in relation to names.

McKinsey (1978) asserts that the causal theory accounts for the manner through which a name originally becomes appended to a place and how it is possible for people that were not present at the point of naming and those not acquainted with the place name to use the name to refer to the location. In summary, the causal theory posits that a name rigidly refers to the bearer (human or place) to which it is causally connected irrespective of any specific details about the bearer and in all possible worlds. Therefore, from the causal theoretical point of view, a place name is a linguistic expression of some objective entity which is tied to the place by some initial speakers of a language through some initial way of application of place name or by introduction provided by some introducer (known as reference borrowing/transmission).

There are two variations of the causal theory, which are: the causal-historical theory of reference, which is the original version of the theory as put forward by Donnellan (1972) and Kripke (1980). This perspective holds that reference passes through links in a causal -historical chain. The other version is the causal-descriptive theory of reference, which is put forward by Lewis (1984). This view posits that there is need to add a minimum descriptive tool to the causal relations between speaker and object. This study adopts the two version of the causal theory.

\section{Research Methodology}


For a proper data analysis and scientific presentation of the research findings, some methodological procedures are followed. The paper adopts a survey research design and the area of study, content wise, is toponymy, with anglicisation as the focus. Geographically, the research work is conducted within the south eastern Nigeria, specifically, the Igbo nation. The study adopts a purposive random sampling technique in picking respondents for the study. Thus, twenty Igbo speakers were randomly drawn from each of the five Igbo states that make up the south eastern Nigeria, namely: Abia, Anambra, Ebonyi, Enugu and Imo states, giving a total number of 100 respondents. The purposefully selected respondents use the Igbo language, both in the spoken and written forms on regular bases. So they are well grounded in the Igbo language and culture.

Data for the study were collected through structured questionnaire and observation. The authors, as native Igbo speakers, with the help of field assistants, collected 140 Igbo toponyms in an ethnographic field work and also through introspection, and subjected them to qualitative analysis by pointing out the alterations caused by anglicisation, through in-depth description of the toponyms; while the questionnaire was quantitatively analysed to get the opinions of the respondents on the effect of anglicisation of Igbo place names on the Igbo language and culture.

\section{Data Presentation And Analysis}

Before we go into data presentation and analysis, it is pertinent to have an overview of the phonotactics and orthographies of the English and Igbo languages. Based on the classification of world languages on their use of pitch, English is an intonation language, which is stress-timed. In other words, English applies pitch to constructions for meaning distinction. Furthermore, in English words, only one syllable is stressed (that is, one syllable attracts primary stress. The syllable that attracts the primary/main stress is the syllable that is emphasised far above the other syllables). In some cases also, a secondary stress can be observed. English has 26 letters of the alphabet and there is no one-to-one correspondence between the letters of the alphabet and the English speech sounds. Observe the English alphabet.

A, B, C, D, E, F, G, H, I, J, K, L, M, N, O, P, Q, R, S, T, U,V,W, X, Y, Z

In addition, based on the English language phonotactics, the following are possible

a. Consonants and vowels can begin words. Example

1. come, go, knight, ear, itch, an, etc

b. Consonant and vowel cluster is possible in English. Example

2. larynx, split, ear, eel, etc

c. Consonants and vowels can end English words. Example

8. car, pharynx, into, toe

On the other hand, Igbo is a tone language and as such is syllable-timed, (see Okorji and Okeke (2009)). In the Igbo language, pitch is applied on syllables for meaning distinction. In other words, all syllables attract prominence in Igbo; hence, all Igbo syllables are tone marked. Igbo has 36 letters of the alphabet and they all have one-to-one correspondence with their speech sounds except ' $n$ '. Therefore, in Igbo, words are spelt the way they are pronounced quite unlike English. Again, Igbo is written with sub dots and tone marks (for lucidity of meaning). Observe the Igbo alphabet.

A, B, CH, D, E, F, G, GB, GH, GW, H, I, I, J, K, KP, KW, L, M, N, N, NW, NY, O, O, P, R, S, SH, T, U, U, V, W, $\mathrm{Y}, \mathrm{Z}$

According to Okorji and Okeke (2009), the Igbo language phonotactic rules stipulate that:

a. Consonants and vowels can begin Igbo words. Example

9. gbàá (kick), bịá (come), ákwụ́kwọ̣ (book), éjùlà (snail), etc

b. Vowel clusters are possible in Igbo not consonant clusters. Example

10. náānị (only), níîlē (all), nwáànỵ̣ (woman) etc

c. Only vowels [e, i, o, u, ụ, ọ, ị, a,] and syllabic [m, n] nasals can end Igbo words. E.g

11. ònyìnyé (gift), ákpị (scorpion), máhádùm (university), ànyịm (ocean)

\section{A. Data Presentation and Analysis}

Data are presented in this section based on the different patterns and/or forms of anglicisation observed in the collected place names. After each group, a brief comment about the group is presented, followed by the detailed analysis at the end of all the presentations.

Group A - Letter doubling

English (wrong) spelling

1. Nsukka

2. Owerri

3. Abatette

4. Obollo-Afor

5. Eziowelle

6. Ajalli

7. Urualla

8. Abba

\author{
Igbo (correct) spelling \\ N̦sụ́kā \\ Òwèrè \\ Àbátētē \\ Úbóló-Àfọ̀ \\ Ézíòwèlè \\ Ájálị \\ Ưrúàlà \\ Àbà
}




\begin{tabular}{|c|c|}
\hline 9. Ozalla & Òzàlà \\
\hline 10. Omamballa & Ớmám̄bālā \\
\hline 11. Ossomale & Ộsọ̀màlè \\
\hline 12. Achalla & Áchàlà \\
\hline 13. Owerre-Ezukala & Òwèré Ézúkāàlà \\
\hline 14. Uratta & Ùrátā \\
\hline 15. Ossah - & Ọ̀sáà \\
\hline 16. Izzi - & İzíì \\
\hline 17. Owerrinta & Òwèrèńtà \\
\hline 18. Umuihitte & Ứmựīhītē \\
\hline 19. Ihitte & İhìtè \\
\hline 20. Afor-Amma & Àfọ̀-Ámā \\
\hline 21. Ezinihitte & Ézínìhìtè \\
\hline 22. Uralla & Ứràlà \\
\hline 23. Ugbelle & Úgbèlè \\
\hline 24. Agballa & Ágbàlà \\
\hline 25. Atta & Àtá \\
\hline 26. Owalla & Ọ̀wàlà \\
\hline 27. Umumpelle & Ứmụ́mpèlé \\
\hline 28. Abbe & Ábè \\
\hline 29. Abbo & Àbọ́ \\
\hline 30. Mgbelle & M̀gbèlè \\
\hline 31. Abbia & Ábịà \\
\hline 32. Effokwe & Èfòkwwè \\
\hline 33. Ama-owelle & Ámá-Òwèlè \\
\hline 34. Onoffia & Ọ̀nọfịà \\
\hline 35. Ekka & Ėkà \\
\hline 36. Ezillo & Ézílò \\
\hline 37. Ezza & Èzàá \\
\hline 38. Effium & Èfịọm \\
\hline 39. Effia-ulo & Éfiá-Ụlọ \\
\hline 40. Ameffia & Áméfịá \\
\hline 41. Edda & Édà \\
\hline 42. Egge & Ègè \\
\hline 43. Nkwerri-Inyi & Ńkwèré-İnyì \\
\hline 44. Offienyi & Ọfịáénȳ̄ \\
\hline 45. Nkwerre & Ńkièrè \\
\hline
\end{tabular}

A close observation of the above toponyms clearly shows that the phonotactic rule of consonant clusters, peculiar to the English language was imposed on Igbo toponyms. As pointed out earlier, Igbo does not accept consonant clusters. So, the doubling of different letters, as seen above makes all the names meaningless in Igbo. The duplicated letters are redundant in Igbo, add no meaning to the toponyms but rather distorts the spelling pattern and senses of the words.

Group B - Introduction of ' $r$ ' and ' $h$ ', whether at word initial, medial or final positions

English (wrong) spelling Igbo (correct) spelling

1. Nkpor

2. Orba

Mkpọ̣ọ

3. Alor

Òbà

4. Obollo-Afor

Ầlọ

5. Eziuzor

Úbóló-Àfọ

6. Ngor-Okpala

7. Ukpor

8. Amorka

9. Umuakpor

10. Ebenator

11. Orsumoghu

Ézíúzò

Ńgộ-Ọkpáàlà

Ừkpọ

Ámọoọāā

Ứmụàkpọ́

Ébénátọ

Òshứmōghò

12. Ubuluzor

Ùbùlụ́zọ

13. Okoh

14. Onneh

Ókó

15. Umuola-Okpulor

16. Ihieorji

Ònéè

Ứmụuọ̀là-Ọkpụ́lọ

Íhì̀ộjị

17. Oror

Ộọ́ 


\begin{tabular}{|c|c|}
\hline 18. Ugwu Avor & Úgwú-Àvọ̀ \\
\hline 19. Agbor & Ágbọ̀ \\
\hline 20. Eziafor & Ézíàfọ̀ \\
\hline 21. Torty & Tọộtị \\
\hline 22. Afor-Ukwu & Àfọ̀-Úkwú \\
\hline 23. Amafor & Ámáàfọ̀ \\
\hline 24. Amaorji & Ámáọjị \\
\hline 25. Avorji & Óvoọjị \\
\hline 26. Avor & Ávọ̄ \\
\hline 27. Owo-Ahiafor & Ọ́wộ-Áhịáàfọ̀ \\
\hline 28. Umuaforukwu & Ứmụàaọúkwwú \\
\hline 29. Akpa-Mbator & Àkpà-Ḿbàtọ́ \\
\hline 30. Eziafor & Ézíàfọ̀ \\
\hline 31. Obuzor & Òbụ́zọ̀ \\
\hline 32. Mkpukpator & Ḿkpụkkpátọ \\
\hline 33. Umuogor & Ứmụọọgọ̀ \\
\hline 34. Obibor & Òbibò \\
\hline 35. Obiuzor & Óbìụ́zọ̀ \\
\hline 36. Umuma-Uzor & Ửmụmá-Ụ́zọ̀ \\
\hline 37. Aboh-Mbaise & Àbọ́-Ḿbàìsé \\
\hline 38. Akabor & Àkàbọ̀ \\
\hline 39. Oborji & Ọbọ̣jì \\
\hline 40. Loryi & Lóyí \\
\hline 41. Afor-Oru & Àfọ̀-Ọ́rụ \\
\hline 42. Orsu & Òsụ́ \\
\hline 43. Offor & Òfọ̀ \\
\hline 44. Amanator & Ámánáātọ \\
\hline 45. Owerri-Nkworji & Òwèré-N̄ikwọoọjjị \\
\hline 46. Orlu & Òlụ́ \\
\hline 47. Ezi-Orsu & Ézí-Ọ̄sụ \\
\hline 48. Amabor & Ámábọ̄ \\
\hline 49. Ogwor & Òggwọ̀ \\
\hline 50. Agbador & Àgbàdò \\
\hline 51. Amakporor & Ámákpọ̄rọ̄ \\
\hline 52. Orda & Ódà \\
\hline 53. Enugunator & Énúgwūnāátộ \\
\hline 54. Ndeaboh & Ǹdéàbọ̀ \\
\hline 55. Umuola Okpulor & Ứmụoọlà-Ọkpụ́lọ̀ \\
\hline 56. Ortor - & Ộtọ \\
\hline
\end{tabular}

In Group B anglicised toponyms, different letters (' $r$ ' and ' $h$ ') are added in each word. The addition (for instance, those added after the word) is also against the Igbo phonotactics because consonants do not end Igbo words. In this set of anglicised toponyms, the feature of not having one-to-one correspondence between the letters of the orthography and the speech sounds, which English is known for, was used in spelling the above Igbo place names. Hence, English tries to realise / $/$ / speech sound in Igbo using 'or' and secondly, realises some Igbo toponyms (Aboh-Mbaise, Ndeaboh, Okoh, etc) as aspirated. If one follows the one-to-one correspondence feature of pronouncing Igbo words, the pronunciation will be marred with $h$ and $r$ colouring that distorts the pronunciation and senses of the toponyms.

\begin{tabular}{|c|c|}
\hline \multicolumn{2}{|c|}{ Group C - Introduction of 'aw' in place of $/ \mathrm{s} /$ and $/ \mathrm{p} /$} \\
\hline English (wrong) spelling & Igbo (correct) spelling \\
\hline 1. Awka & Óká \\
\hline 2. Awkunawnaw & Ọ́kụnnáánọ̄ \\
\hline 3. Awgu & Ọgwụ̀ \\
\hline 4. Nawfia & Nọọ̣fịā \\
\hline 5. Awkuzu & Ọkụ́zụ̀ \\
\hline 6. Amawbia & Ámáọ̄bịà \\
\hline 7. Nawgu & Nọọ̣gụ \\
\hline 8. Awka-Etiti & Ọ́ká-Ētìtì \\
\hline 9. Awgbu & Ọgbụ́ \\
\hline 10. Nawfija & Nọộfịjā \\
\hline 11. Awgunta & Ógụnntà \\
\hline 12. Awlaw & Ọ́lọ́ \\
\hline
\end{tabular}




\section{Awhum Ọ̀húm}

In Group C toponyms above, ' $a$ ' and ' $w$ ' are realised together as / $/$ or / $/$ / in English but in Igbo, ' $a$ ' and ' $w$ ' are different letters pronounced differently. So, pronouncing them as one sound violates the Igbo pronunciation rule and creates consonant cluster, which also, is another deviation from Igbo spelling pattern as seen in Group A toponyms.

Group D - Using ' $n$ ' in place of ' $m$ '

English (wrong) spelling

1. Nkpor

Igbo (correct) spelling

2. Nkpologwu

3. Nkpakpi

4. Nkporo

5. Nkpa

Mkpọò

M̀kpólógwū

6. Ngboko

Mkpàkpi

M̀kpóró

M̀kpà

7. Nbawsi

Mgbókó

8. Nkpuruta - Ndiolumbe

9. Nkputa

M̉báwụsì

Ḿkpụ̣ụ̂tá-Ńdịōlūmbè

Mkpụtà

In the Igbo language, the nasal homorganicity rule manifests on written words, as well as in the pronunciation of the words, following the rule of one-to-one correspondence between the letters and the speech sounds. Each nasal consonant in Igbo is selected by the appropriate consonant based on the place of articulation of the consonant sound following the nasal sound. Hence, ' $\mathrm{m}$ ' or /m/ will be selected by any labial or labia-velar consonant, ' $\mathrm{n}$ ' and /n/ will be selected by other places of articulation apart from velar consonants and ' $\dot{\mathrm{n}}$ ' and $/ \mathrm{h} /$ are selected by velar consonants. But in the anglicised Igbo words, this rule is violated as observed in Group D toponyms.

Group $E$ - The use of ' $g$ ' in place of ' $g$ '

English (wrong) spelling Igbo (correct) spelling

1. Enugu

2. Awgu

3. Enugu-Agidi

4. Enyiogugu

5. Agbaogugu

Énúgwū

Ògwụ̀

Énúgwú-Ágịdị

Ényíògwùgwù

Ágbáògwùgwù

There is no voiced labialized velar plosive /gw/ in English, hence the replacement of /gw/ in Igbo with the voiced velar plosive /g/ in English. This replacement also violates the Igbo spelling rule and renders the toponyms meaningless.

Group F - Omission of letters

English (wrong) spelling

1. Anambra

Igbo (correct) spelling

2. Amansea

3. Neni

Ánám̄bārā

Ámánéésì̀

4. Alke

Ńnēnī

5. Ibo

Àlịíkē

Ìgbò

As pointed out earlier, Igbo is a syllable-timed language and as such, each syllable attracts prominence in pronunciation. On the other hand, English is stress-timed. In other words, only one syllable is stressed while other syllables are unstressed. Based on the syllable timing of Igbo words, all tone bearing units (vowels and syllabic nasals) are tone marked. So, the omission of letters (vowels) in examples (1-4) in Group F violates the Igbo spelling rule and affects the meanings of the words. In (5), the omission of ' $\mathrm{g}$ ', because of the absence of /gw/ in English (as pointed out in Group E) also renders the toponym meaningless.

Group G - Others

English (wrong) spelling

1. Onitsha

2. Imo River

3. Umuchukwu

4. Umunze

5. Umuanaga

6. Umuike

7. Umuachina

8. Umukalu

9. Isioji

Examples $(1 \& 2)$ in Group $G$ anglicised toponyms exhibit complex anglicisation features. In 'Onitsha', ' $t$ ' was introduced and $/ \mathrm{f} /$ replaced with $/ \mathrm{f} /$ with all the vowels not dotted. In 'Imo River', we have a combination of one Igbo word 'Imo' and one full fledged English word 'River'. Examples ( 3 - 9), just like all the toponyms examined were not dotted. Again, these toponyms have a peculiar problem because they contain both dotted and the non-dotted letters that are acceptable Igbo letters and distinctive speech sounds. Therefore, using ' $u$ ' and /u/ for 'ụ' and / / is a serious

\author{
Igbo (correct) spelling \\ Ọnịchà \\ Òshìmìrì Ímò \\ Ứmụchúkwú \\ Ứmụ̀nzè \\ Ứmụànàgà \\ Ưmựíkē \\ Ứmụáchíànà \\ Ứmứkālụ \\ Ísíójị
}


anglicisation crime because there is no Igbo word like 'umu' /umu/. In (9), 'oji' stands for 'black' while 'ọjị' means 'iroko tree', so 'Isioji' has a different sense from 'Isiojị' (see section 5.2.1 for details)

\section{B. Data Analysis}

\section{The Nature of Anglicisation of Igbo Place Names}

The Igbo language has a conventional orthography, specifically designed for writing the Igbo language, which is different from the orthography of the English language. The respondents acknowledged that certain characteristics make the Igbo writing system different from that of the English language. This is revealed in the data analysed and collated from the questionnaire as 91 respondents, representing $91 \%$ of the research population are aware, acknowledge, and strongly agree that sub dots and tone marks are necessary in the writing system of the Igbo language. 8 respondents, representing 8 percent of the population, are aware and agree that sub dots and tone marks are necessary in the writing system of Igbo language. None of the respondents strongly disagree with this fact, while only 1 respondent, representing only $1 \%$ of the research population, disagrees with this fact. This buttresses our claim that the Igbo language is written with sub dots and tone marks; otherwise, the meaning of words would be lost. Therefore, with $99 \%$ of the population in unison that the Igbo language makes use of sub dots and tone marks, there is a high level of awareness among the people on the importance of sub dots and tone marks in the realisation of the correct pronunciation and the required meaning in writing Igbo toponyms and in distinguishing between words and expressions with the same morphological form, (observe the data presented in 5.1). In the above data, no Igbo toponym was written with sub dots or with tone marks. Based on the Igbo orthographic system and phonotactics, all the toponyms under English spelling are not Igbo words because they neither follow the Igbo writing system nor bear Igbo meaning(s).

Specifically, an Igbo toponym, depending on the group it falls under, based on the above classification, is altered in one way or the other based on how anglicisation affected it. The answers provided by the respondents in the questionnaire provided answers to this. On whether Igbo place names are spelt and written following the English language writing system in most formal and informal situations by omitting some words, doubling some letters, adding ' $r$ ', ' $h$ ', 'aw', or by replacing the bilabial nasal $/ \mathrm{m} / \mathrm{with}$ the alveolar nasal $/ \mathrm{n} /$, the majority of Igbo speakers and users ( $96 \%$ of the population) acknowledged that Igbo toponyms are anglicised by adding ' $r$ ', ' $h$ ', 'aw', etc. Only $4 \%$ of the respondents did not see anything wrong with anglicisation of Igbo names; and so, view it as proper to write Igbo place names thus:

'Ọ́ká' is written as *Awka; 'Ọkụnnànọ̣’ as *Awkunawnaw; 'Ọzàlà' as *Ozalla; 'M̀kpọọ̣’ as *Nkpor; 'Ụrátā' as *Uratta; 'Òwèrè' as *Owerri; 'Ágbáògwùgwù' as *Agbagugu, etc, (observe data groups A-G above).

\section{Effects of Anglicisation on Igbo Place Names Based on the Opinions of the Respondents}

The efforts made to determine the effects of anglicisation on Igbo place names also elicited several responses from the respondents. 90 respondents, representing $90 \%$ of the research population, strongly agree that anglicisation of Igbo place names alter their proper pronunciation and meanings. They also strongly agree that anglicisation equally leads to the loss of history and cultural heritage of Igbo towns specifically, and Igbo people in general. Furthermore, they agree that these negative effects of anglicisation have adverse effects on the growth of the Igbo language and culture. Only 10 respondents representing $10 \%$ of the research population disagree that anglicisation of Igbo place names does not have the above stipulated effects on the Igbo language and its speakers/users.

Based on our data presentation above, there is obvious confusion in any attempt one makes to properly pronounce the place names, especially if one has not encountered such place names being properly pronounced by someone of Igbo origin or one that knows the correct pronunciation. This fact denies the Igbo language of its prestigious quality of being written and pronounced exactly as its phonology demands, without any ambiguity. This inability to realise the proper phonology of these place names also results in loss of meanings associated with the place names. Even the word 'Igbo' is anglicised as '*Ibo' by replacing the digraph $/ \mathrm{gb} /$ with $/ \mathrm{b} /$. This omission distorts the word and makes it completely meaningless. Unfortunately, the study and teaching of English through English texts and teachers promote anglicisation of Igbo toponyms in schools.

In addition, place names are usually derived out of certain historical events or explanations associated with such places. In many cases, place names are given to places based on the person or people who settled in those places at a certain period in history, or those who had done something extraordinary or phenomenal. For instance, place names beginning with morphological expressions such as 'Ứmụ̂' meaning 'children', tell the story that the people inhabiting the place are descendants of a common ancestor. Furthermore, a renowned or powerful phenomenon such as a known 'God,' whose name is attached to the word/morphological expression 'ụmụ' for instances, Ụmụchukwu (God's children), Ụmụeze (children of Eze), Ụmụanaga (children of Anaga), Ụmụike (children of Ike), Ụmụchiana (children of Chiana), Ụmụkalụ (children of Kalụ), etc. are a pointer that they are all descendants of God or the man reflected using 'ụmụ'. Any form of alteration distorts the name and makes it meaningless as observed in group G, where 'ụmụ' was anglicised without sub dots.

Some place names that are realised from the efforts made to tell the story of the place have lost their stories due to anglicisation. For instance, a place name like 'Amaọọịa' (its full form is 'Ama ndị ọbịa'), is a town in Anambra state, which translates to 'Land of guests or strangers. Here, 'Ama' means 'place' and 'Ọbịa' means 'guest or stranger'. This toponym 'Amaọobịa' was given to a group of visitors, guests or strangers, by the Igbo people of Oka (which is anglicised as Awka), to dwell among them since they were stranded, having been driven away from their original abode 
due to certain natural, man-made, environmental or ecological factors, etc. Due to anglicisation, however, this place name has come to be continually written as Amawbia. The anglicised form has completely changed the actual spelling of the place name and, consequently, negatively affecting the perception, semantics, history and cultural story associated with the place. The same loss of semantics, history and cultural heritage is applicable to all the toponyms presented above.

Furthermore, $90 \%$ of the research population, strongly agree, maintain, and are aware that the above-listed instances of anglicisation of Igbo place names weaken and endanger the Igbo language. 91 respondents, representing $91 \%$ of the population strongly agree that the grave consequences stated above face the Igbo language if nothing is done about the anglicised Igbo toponyms. On the other hand, 9 respondents, representing $9 \%$ of the research population strongly disagree with the submissions of 91 respondents, stating that they are not aware that anglicisation weakens and endangers the Igbo language.

Furthermore, majority of the respondents, $89 \%$ strongly disagree that anglicisation does not contribute in any way in aiding people to learn how to pronounce and write the Igbo language faster and better. This issue was raised because some respondents (11 of them) were of the opinion that when one anglicises Igbo words, it makes the words easier to pronounce but the majority disagreed because according to them, the one-to-one correspondence rule makes Igbo pronunciation easier than the English pronunciation. Summarily, the perception of the respondents with regard to the effects of anglicisation of Igbo toponyms is summarised below under the following headings:

\section{- Mispronunciation, misspelling and loss of Igbo letters:}

Mispronunciation of Igbo words is a regular occurrence if one tries to pronounce anglicised Igbo toponyms. For example, Igbo letters with sub dots such as 'ị', 'ọ', 'ụ' are pronounced as /I, o, v/, respectively, but when the sub dots are omitted through anglicisation, by writing and pronouncing them as $[\mathrm{i}, \mathrm{o}, \mathrm{u}]$, they are pronounced the same way as their corresponding Igbo phonemes $/ \mathrm{i}, \mathrm{o}, \mathrm{u} /$. This is the same as writing a different letter when one intends to write another letter, such as writing ' $b$ ' in place of ' $d$ ' or ' $n$ ' in place of ' $m$ '. This kind of situation also results in misspellings such as 'Ọka' as 'Awka', 'Alọ' as 'Alor' or 'Ụmụalọ' as 'Umualor', etc. Given the consistent anglicisation of Igbo place names and Igbo writing in general, the language faces the danger of losing several of its letters which are always misrepresented, and, in fact, omitted in writing, such as 'ị', 'ọ’, 'ụ', '

\section{- Language endangerment/death:}

Anglicisation of Igbo place names is gradually resulting in the Igbo language attrition and endangerment. When Igbo place names are anglicised as observed from the analysis, the orthography of the Igbo language suffers. The language loses Igbo 'flavour' and children grow up writing and spelling Igbo toponyms like English words. Thus, when anglicisation makes it difficult for Igbo expressions to be properly articulated by speakers and users, the frequency and quality of its usage in speaking and writing reduce due to limited appreciation. This situation endangers the Igbo language and would actually lead to language death if remedial actions are not urgently taken.

\section{- Poor comprehension of meaning:}

Poor comprehension of meaning is another effect of anglicisation of Igbo place names deduced from the responses of the respondents. This implies that the meanings/senses associated with Igbo place names, as well as majority of Igbo written words, sentences and other kinds of Igbo written expressions become difficult for readers of Igbo writings to grasp. For instance, the anglicisation of 'Isiojjị’as 'Isioji' changes its meaning. 'Ísíọjị' means the head of Iroko (the head of a giant species of tree in Igbo nation), while 'Isioji' means (black head, where 'ísí' means head, 'ọjị' means iroko tree, and 'òjí' means black). Similarly, 'Amanesii' means 'a clan with six tribes', where 'ama' means 'tribe(s)' and 'esii' is the dialectal variant of 'isii' - 'six', but the anglicised form '*Amansea' has no meaning at all.

\section{- Loss of history, originality, pride/value and cultural heritage of the Igbo language:}

From our analysis, the respondents express their view that anglicisation causes loss of history, originality, pride/value and cultural heritage of the Igbo language. For instance, there is a reason behind every Igbo place name. These reasons constitute the history and cultural heritage underlying these Igbo place names, which are sources of their pride/value and cultural heritage. The views of the respondents are in line with the words of Jena \& Padhi (2015, p. 49), which go thus:

A place is known to the outside world through its identity. The travellers visit places by their names in the course of their journey. Place names of a region speak about the geographical and historical peculiarities revealing cultural identities of the people. Place names do speak when there is no history. Place names narrate their interesting characteristics. Hence, a place name is an expression of the name giver's thought process.

As previously noted about Group G, place names bearing the initial morpheme or word 'ụmụ' meaning 'children', tell a story of the descendants of a common ancestor or adherents to a particular man and even God. Anglicising these place names make them lose their history and cultural heritage.

\section{- Hindering proper learning of Igbo language:}

The Igbo language has its own orthography and phonotactics; therefore, learning the spoken form of the Igbo language within a formal setting requires learning the orthography of the language as well. However, with the anglicisation of Igbo place names in particular and other Igbo expressions in general, proper and actual learning of correct spellings and expressions is denied the Igbo native speakers learning Igbo for literacy purpose and the second language learners (L2) of the language, especially with English as the lingua franca in Nigeria. 


\section{- Showing an extension of the powers of colonisation and imperialism of the English language:}

The above point was raised by two of the respondents used for the research. The effects of anglicisation as noted from the analysis involve the denigration of the Igbo language and its orthography for the exaltation of the English language. This leads to a more appreciation and adoption of the 'exalted language' as against the 'less appreciated language', which may be forced into endangerment and consequent death if the trend is left unchecked. This is also an extension of colonisation and imperialism of the British. Officially, Nigeria has gained her independence but, unofficially, Nigeria is seriously under colonisation through anglicisation.

\section{SUMMARY OF THE FINDINGS}

The sensitive issue of anglicisation of Igbo place names is one that provokes constant attention in the minds of speakers and users of the Igbo language. This is evident in the findings of this study as presented below:

- Based on the data used (see section 5.1) Igbo toponyms are anglicised through different anglicisation processes like doubling letters, introduction of ' $r$ ' at different positions in words, introduction of 'aw', using ' $n$ ' in place ' $m$ ', the use of ' $\mathrm{g}$ ' in place of ' $\mathrm{gw}$ ', no sub dots and tone marks on all the toponyms.

- Secondly, more than $90 \%$ of the respondents are aware and maintain that Igbo toponyms are anglicised. They strongly agree that there are grave consequences facing the Igbo language presently, and if nothing is done to the high wave of anglicisation of Igbo words, and/or guarding against further anglicisation of more Igbo toponyms, more harm will be done to the language. Some of the negative effects according to our findings include but are not limited to the following: improper written forms of Igbo toponyms, mispronunciation of Igbo toponyms, wrong assignment of meanings to Igbo place names caused by wrong spelling, loss of Igbo cultural heritage and value, (which place names help to protect), gradual loss of Igbo identity, among others.

- Finally, the analysis reveals potential loss of some Igbo letters of the alphabet, especially the Igbo vowels and syllabic nasal with sub and super dots [o, ụ, ị, n]]; attrition of Igbo toponyms specifically, and other Igbo words in general is imminent; and the Igbo language endangerment which is a precursor to language death.

From the analysis and discussions so far, it is not out of place for a reader to have an already perceived possible solutions for overcoming anglicisation of Igbo place names. Below are some solutions to the sociolinguistic phenomenon of anglicisation of Igbo toponyms.

- Emphasising the use of Igbo orthography in writing Igbo place names at all levels, contexts or situations of writing

When one writes in the English language, the tendency is for the writer to adopt English orthography in representing Igbo place names whenever one encounters them, thus, substituting Igbo letters for similar English letters. This trend should be discouraged at all levels of writing, formal or informal, ensuring that sub dots and tone marks (where required) are placed wherever appropriate. For instance:

5a. I am going to $O k a$ to see my friend who is a native of Alọ. This should not be

\section{b. *I am going to Awka to see my friend who is a native of Alor}

- Teaching the writing convention of the Igbo language at all levels and contexts of teaching

Here, teachers should always endeavour to teach the writing convention of the Igbo language to students at all levels of education. Emphasis should always be placed on those letters and sequence of sounds which are usually anglicised when written. For instance, the Igbo speech sound /o/, which is represented by the letter 'o' is usually anglicised as 'o', 'aw' or 'or', which signifies a transfer of the obvious characteristic of irregularity involved in representing English speech sounds in line with their alphabet, to the Igbo language, which has a one-to-one correspondence between every speech sound and the letter used to represent it, with the exception of ' $n$ '. This one-to-one correspondence between Igbo letters and their phonemes is shown thus:

$\begin{array}{lllllllll}\text { Letters: } & \mathrm{A} & \mathrm{B} & \mathrm{CH} & \mathrm{D} & \mathrm{E} & \mathrm{F} & \mathrm{G} & \mathrm{GB} \\ \text { Pronunciation: } & / \mathrm{a} / & / \mathrm{b} / & / \mathrm{g} / & / \mathrm{d} / & / \mathrm{e} / & / \mathrm{f} / & / \mathrm{g} / & / \mathrm{gb} / \\ \text { Letters: } & \mathrm{GH} & \mathrm{GW} & \mathrm{H} & \mathrm{I} & \mathrm{I} & \mathrm{J} & \mathrm{K} & \mathrm{KP} \\ \text { Pronunciation: } & / \mathrm{y} / & / \mathrm{g}^{\mathrm{w}} / & / \mathrm{h} / & / \mathrm{i} / & / \mathrm{l} / & / \mathrm{d} / & / \mathrm{k} / & / \mathrm{kp} / \\ \text { Letters: } & \mathrm{KW} & \mathrm{L} & \mathrm{M} & \mathrm{N} & \mathrm{NW} & \mathrm{NY} & \tilde{\mathrm{N}} & \mathrm{O} \\ \text { Pronunciation: } & / \mathrm{k}^{\mathrm{w}} / & / \mathrm{l} / & / \mathrm{m} / & / \mathrm{n} / & / \mathrm{h}^{\mathrm{w}} / & / \mathrm{n} / & / \mathrm{g} / & / \mathrm{d} / \\ \text { Letters: } & \mathrm{O} & \mathrm{P} & \mathrm{R} & \mathrm{S} & \mathrm{SH} & \mathrm{T} & \mathrm{U} & \mathrm{U} \\ \text { Pronunciation: } & / \mathrm{J} / & / \mathrm{p} / & / \mathrm{r} / & / \mathrm{s} / & / \mathrm{J} / & / \mathrm{t} / & / \mathrm{u} / & / \mathrm{J} / \\ \text { Letters: } & \mathrm{V} & \mathrm{W} & \mathrm{Y} & \mathrm{Z} & & & & \\ \text { Pronunciation: } & / \mathrm{v} / & / \mathrm{w} / & / \mathrm{j} / & / \mathrm{z} / & & & & \end{array}$

- Replacing current maps and official documents bearing Igbo place names and other Igbo expressions in an anglicised format with the appropriate Igbo alphabetic symbols

Many official documents bearing Igbo place names, even charts and maps used in teaching students at various levels of education, within and outside Nigeria, contain anglicised versions of Igbo toponyms. Majority of maps online also contain anglicised versions of Igbo place names. Documents, which present or discuss issues concerning or relating to Igbo place names are also anglicised. These maps and various kinds of documents containing these anglicised Igbo place names should be replaced with versions containing appropriate representation of Igbo place names and expressions in general. 
- Conscientizing the Igbo on the need to spell and write Igbo toponyms properly, especially those that see the English spelling pattern and rules as easier than these of Igbo

When the above solutions are put into practice, the Igbo language development will be enhanced and the use of Igbo for wider communication will be greatly encouraged.

\section{CONCLUSION}

The findings of this study have shown that colonisation comes in different forms, and anglicisation is an extension of the power of colonisation and imperialism of the English language on the Igbo language. On the surface, one may casually wave aside the phenomenon of anglicisation as an expression of mere sentiment but it is a fact that the identity of a people and their stories, as well as histories, philosophies and beliefs are hugely embedded in many of their place names, as the findings in this paper reveal.

In conclusion, therefore, the significance of the study cannot be overemphasised because it draws the attention of the Igbo people, the Igbo native speakers, as well as learners of the Igbo language to the existence and increasing trend of anglicisation in the language, especially as it concerns the names of places, which are located within the Igbo geographical areas. By drawing attention to this negative sociolinguistic phenomenon, the study informs the readers about the nature of anglicisation of Igbo place names, so as to increase their consciousness of the trend. It equally explains the consequences or effects of anglicising of Igbo place names, and suggests solutions to the problem. The study also cautions the Igbo and non Igbo, who are involved in this practice to desist from it, be descriptive in analysing Igbo toponyms, and use the correct Igbo orthography in writing Igbo toponyms, and other Igbo words in general, in order to preserve the language's originality for a better speaking, writing and learning of the language by the emerging generation of speakers and learners.

\section{REFERENCES}

[1] Bridge, C. \& Fedorowich, K. (eds.) (2003). The British world: Diaspora, culture and identity. London: Frank Cass Publishers.

[2] Coupland, N. \& Thomas, A. R. (1990). English in Wales: Diversity, conflict, and change. Clevedon: Multilingual Matters Limited.

[3] DeLozier, G. H. (2016). Data and methods for Gazetteer Independent Toponym Resolution. Thesis presented to the Faculty of the Graduate School of the University of Texas at Austin in partial fulfilment of the requirements for the Degree of Master of Arts. Retrieved from https://repositories.lib.utexas.edu/bitstream/handle/2152/38766/DELOZIER-THESIS2016.pdf? sequence $=1$. Accessed on 9/11/2016.

[4] Donnellan, K. S. (1972). Proper names and identifying descriptions. In D. Davidson \& G. Alaman (ed). Semantics of natural language (pp 356-379). Dordrecht: D. Reided.

[5] Domingues, C. \& Eshkol-Taravella, I. (2015). Toponym recognition in custom-made map titles. International Journal of Cartography. DOI: 10.1080/23729333.2015.1055935. <hal-01174721>.

[6] Frege, G. (1952). On sense and reference. In P. Geach \& M. Blacks (eds.). Translations from the philosophical writings of Gottlob Frege (pp. 36 - 56). Oxford: Oxford University Press.

[7] Guyot, S. \& Seethal, C. (2007). Identity of place, places of identities, change of place names in post-apartheid South Africa. The South African Geographical Journal, 89 (1), 55- 63.

[8] Hutabarat, I. R. \& Pratama, M. U. (2016). Utilizing open street map tags for road toponyms in post tsunami reconstruction area: The lesson from Aceh, Indonesia (8147). FIG working week 2016. Christchurch, New Zealand, May 2 - 6, 2016. Retrieved from https://www.fig.net/resources/.../fig.../ts08g/TS08G_hutabarat_pratama_8147_abs.pdf. Accessed on 9/11/2016.

[9] Jena, S. \& Padhi, P. (2015). Pre-requisites of designing and developing a dictionary of place names of Odisha: A geographical information source. International Journal of Library and Information Studies, 5(3), 49-55.

[10] Kripke, S. (1980). Naming and necessity. Boston: Basil Blackwell.

[11] Lewis, D. K. (1984). Putnam's paradox. Australasian Journal of Philosophy, 62(3), 221-236.

[12] McKinsey, M. (1978). Kripke's objectives to description theories of names. Canadian Journal of Philosophy, 8(3), $485-497$.

[13] Mukerjee, R. (1958). A history of Indian civilisation. Bombay: Hind Kitabs Limited.

[14] Okorji, R.I. \& Author. (2009). The effects of the difference between the sound systems of English and Igbo on the effective learning of English in Nigeria schools. NKỌÀ, Nkuzi na Oтити Asusu Igbo, 2, 25 - 36.

[15] Price, F. S. (2007). Success with Asian names: A practical guide for business and everyday life. London: Nicholas Brawley Publishing House.

[16] Russell, B. (1905). On denoting. Oxford: Oxford University Press.

[17] Shamhrain, A. S. (1999). Place names as indicators of settlement. Archaeology Ireland, 5(3), 19-21. Wordwell Limited.

[18] World Heritage Encyclopaedia (2016). Available in Anglicised worldebooklibrary.net/articles/Anglicised. Retrieved on $8 / 11 / 2016$. 


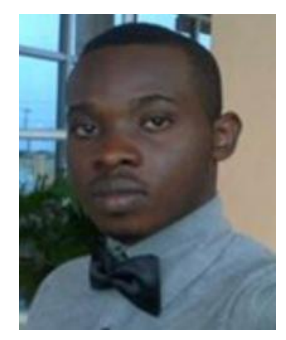

Kelvin Francis Obitube was born in Onitsha in Anambra State of Nigeria. He is a lecturer in the University of Nigeria, Nsukka. He holds core interest in applied linguistics, pragmatics and sociolinguistics. He is also interested in the core areas of Linguistics such as phonetics, phonology, morphology, syntax and semantics.

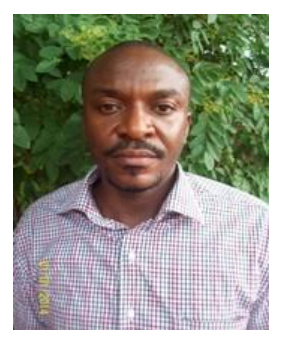

Chukwuma Onyebuchi Okeke was born at Awgu in Enugu State of Nigeria. He is a lecturer in the University of Nigeria, Nsukka. He is a fellow of the African Humanities Programme (AHP) organized by the American Council of Learned Society (ACLS). He is interested in the core areas of Linguistics via phonology, morphology, syntax and semantics. 